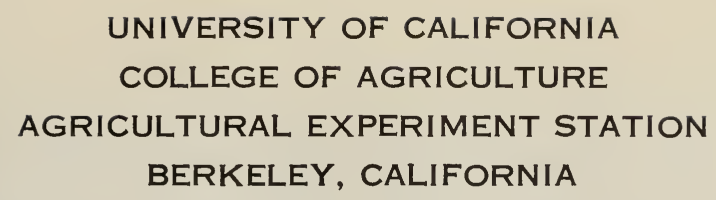

\title{
THE EFFECT OF PRUNING IN THE TRAINING OF YOUNG OLIVE TREES
}

\author{
H. E. JACOB
}

\section{BULLETIN 568}

JANUARY, 1934 
Digitized by the Internet Archive in 2012 with funding from University of California, Davis Libraries 


\section{THE EFFECT OF PRUNING IN THE TRAINING OF YOUNG OLIVE TREES ${ }^{1}$}

H. E. JACOB ${ }^{2}$

The investigation reported in this paper constitutes a continuation and an expansion of the investigation reported by Bioletti ${ }^{3}$ in Bulletin 348 . The results of the former investigation show a very decided depressing effect on young olive trees resulting apparently from both very heavy and moderately heavy pruning. Trees which had received four successive severe winter prunings made only one-tenth as much average growth as was made by the unpruned trees. Those which had received two light summer prunings and two heavy winter prunings made only one-fourth the average growth of the unpruned trees. Furthermore the unpruned trees were the first to come into bearing and their form was equal to or better than that of the pruned trees. These results suggested the idea that at least the Mission and probably all varieties of olive trees would develop faster, bear earlier, and possibly attain a better form if left unpruned, or practically so, until they reached bearing age.

Certain difficulties were encountered in carrying out the former investigation. In one part of the plot the trees did not receive sufficient water owing to a shortage of irrigation water at the time it was needed. Here the depressing effect of severe pruning was less evident probably because the unpruned trees sooner felt the limiting effect of restriction in water supply. In the part receiving sufficient water, the effect of competition between the pruned and unpruned was evident after the fourth season. The unpruned trees developed most rapidly, monopolized more than their share of soil, and shaded the smaller pruned trees during parts of each day. Consequently the pruned trees suffered not only from the depressing effect of the pruning but from competition with their vigorous rivals - the unpruned trees-for water, light, and soil nutrients. It seemed advisable therefore to repeat the experiment in a modified form and also to extend the work to varieties other than the Mission, which alone was used in the original experiment.

1 Received for publication August 11, 1933.

2 Associate in Viticulture.

3 Bioletti, F. T. Pruning young olive trees. California Agr. Exp. Sta. Bul. 348: 87-110. Figs. 1-8. 1922. 
A new experimental plot was planted in 1924. The trees of this plot have reached bearing age and the phase of the investigation dealing with the pruning of young trees has been completed. The plan of the experiment and the results obtained are given in the following pages.

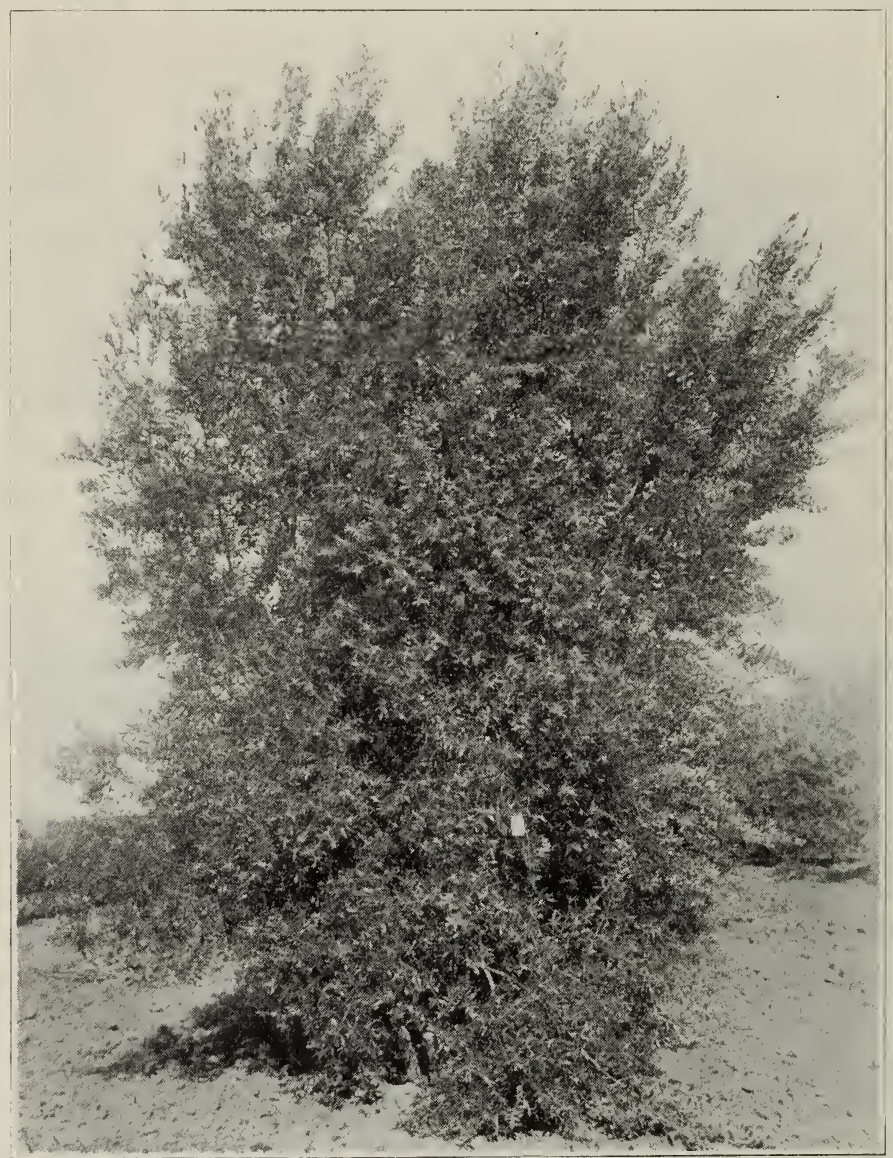

Fig. 1.-Mission tree 5 years old having had no pruning. Illustrates system $A$ before pruning in 1929 .

\section{VARIETIES USED}

Mission, Manzanillo, Sevillano, and Ascolano-the four varieties of olives of most importance in California-were used. The Mission tree is of upright growth and very vigorous (fig. 1). The Manzanillo is drooping and less vigorous (fig. 11). The Sevillano and Ascolano are nearly as vigorous as the Mission and intermediate between the Mission and Manzanillo in habit of growth (fig. 4). 


\section{PRUNING SYSTEMS USED}

Variations in pruning were confined to winter pruning. Summer pruning was limited to the removal of shoots from the rootstocks and of water-sprouts on the trunks. No summer pruning was done in the tops of any of the trees. Five systems of winter pruning were employed.

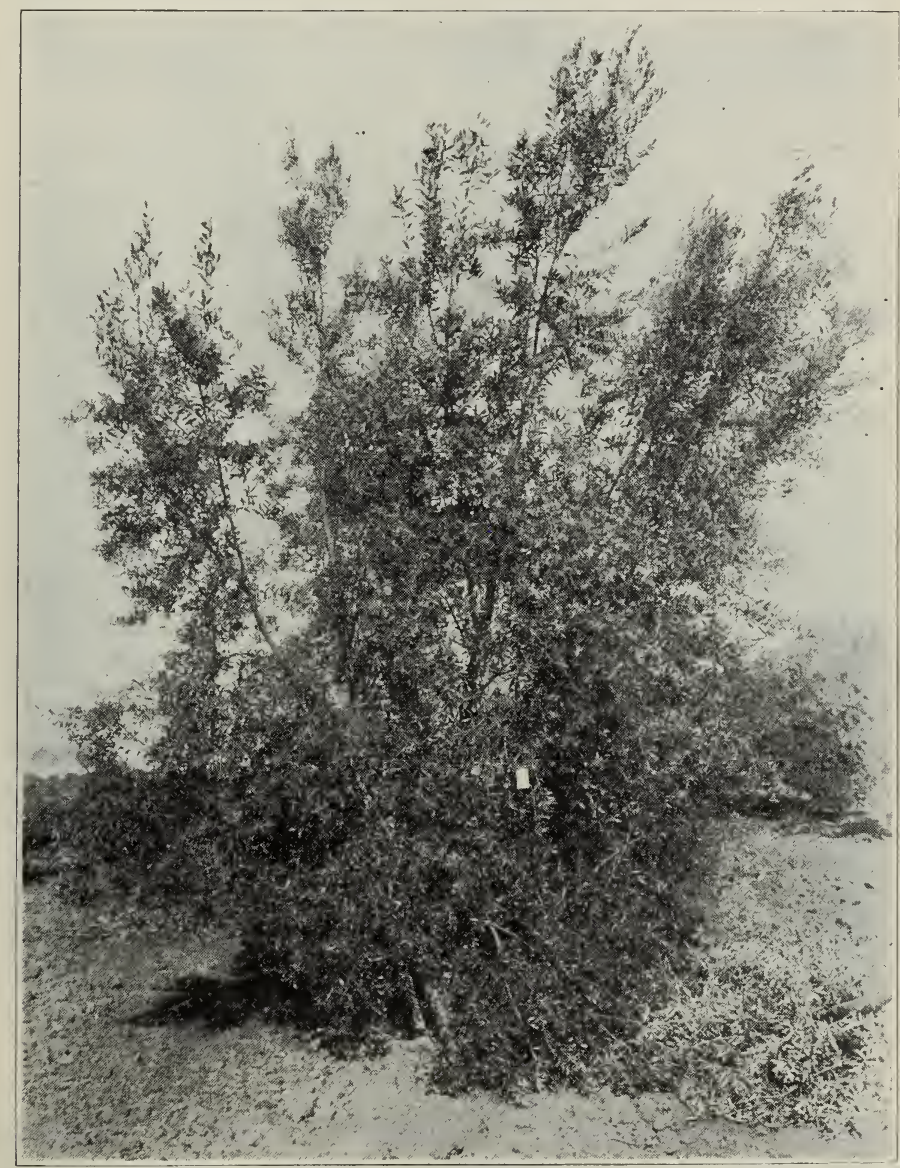

Fig. 2.-Mission tree 5 years old shaped by a single pruning. The tree has been opened up by removing several large branches and lightly thinning out the laterals on the remaining branches. Illustrates system $A$ after pruning in 1929. Same tree as in figure 1.

System A: Under this system little or no pruning of the branches was practiced until the trees reached bearing age. During the first five years an occasional ill-placed branch was removed where it seemed evident that its removal later would damage other branches needed to form the 
permanent framework of the tree. Suckers or water-sprouts at or below the surface of the soil were removed several times each year during the first three years. No thinning of twigs or small branches was done on any part of the tree during the first four years.

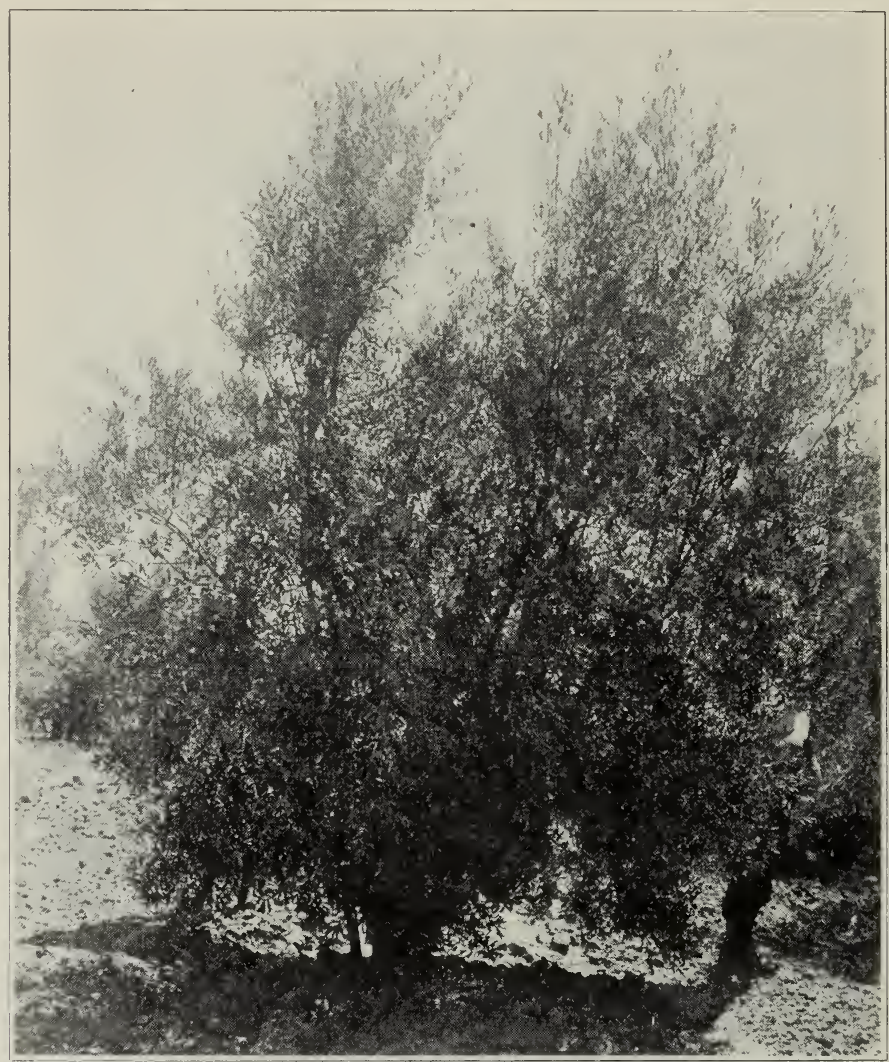

Fig. 3.- Mission tree 5 years old which has been shaped by light annual pruning. Illustrates system $C$ after pruning in 1929 .

A light crop was borne the fifth season. The following winter the trees were opened up by removing all of the main branches except four, five, or six scaffold branches on each tree. These reserved branches were selected so as to form as nearly as possible a hollow inverted cone with sides rising at an angle of about 60 degrees from the horizontal. After the removal of superfluous large branches, the lower half of the tree was thinned out by the removal of twigs or by cutting back to laterals as much as appeared necessary to prevent overbearing. No topping of the main branches was done. (See figs. 1 and 2, 4 and 5, 11 and 12.) 
During the sixth and seventh winters the pruning consisted in the removal of water-sprouts and light thinning of dense portions of the trees.

System $B$ : This system is identical with system $A$ except that the very dense skirt of small branches on the lower part of the tree was thinned out the third winter.

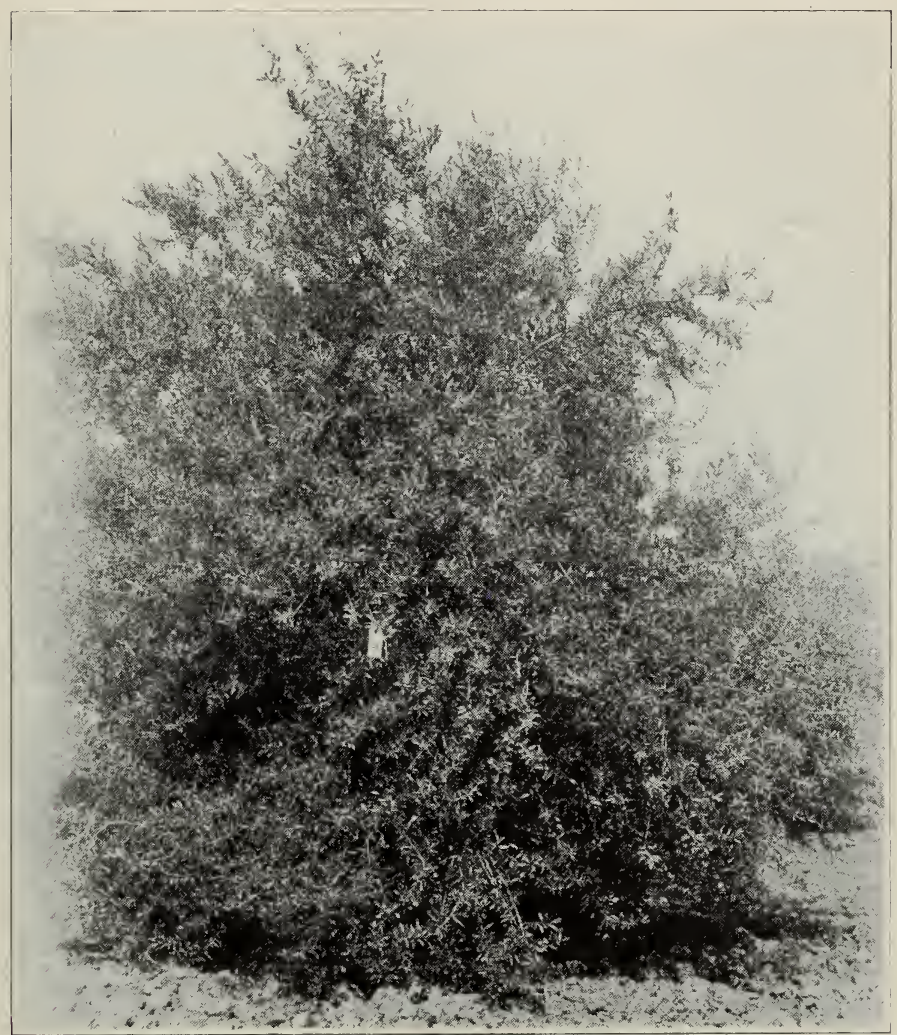

Fig. 4.-Ascolano tree 5 years old having had no pruning. Illustrates system $A$ before pruning in 1929.

System C: This may be designated as light anmual pruning. At the first or second winter pruning, from three to five branches were selected for scaffold branches from which the framework of the tree was developed (fig. 3). These were selected so as to be well distributed around the trunk and with their respective origins from the trunk as far apart vertically as the development of the individual tree would permit.

Each year branches not desired for the scaffold were repressed by shortening, or were removed entirely where their presence threatened to interfere seriously with the development of the desired form. Surplus 
hranches were allowed to remain wherever this was possible without seriously affecting the development of the scaffold branches. To obtain an even development of the permanent branches, the few that grew much more vigorously than the others were restrained by cutting back to a lateral extending in the desired direction.

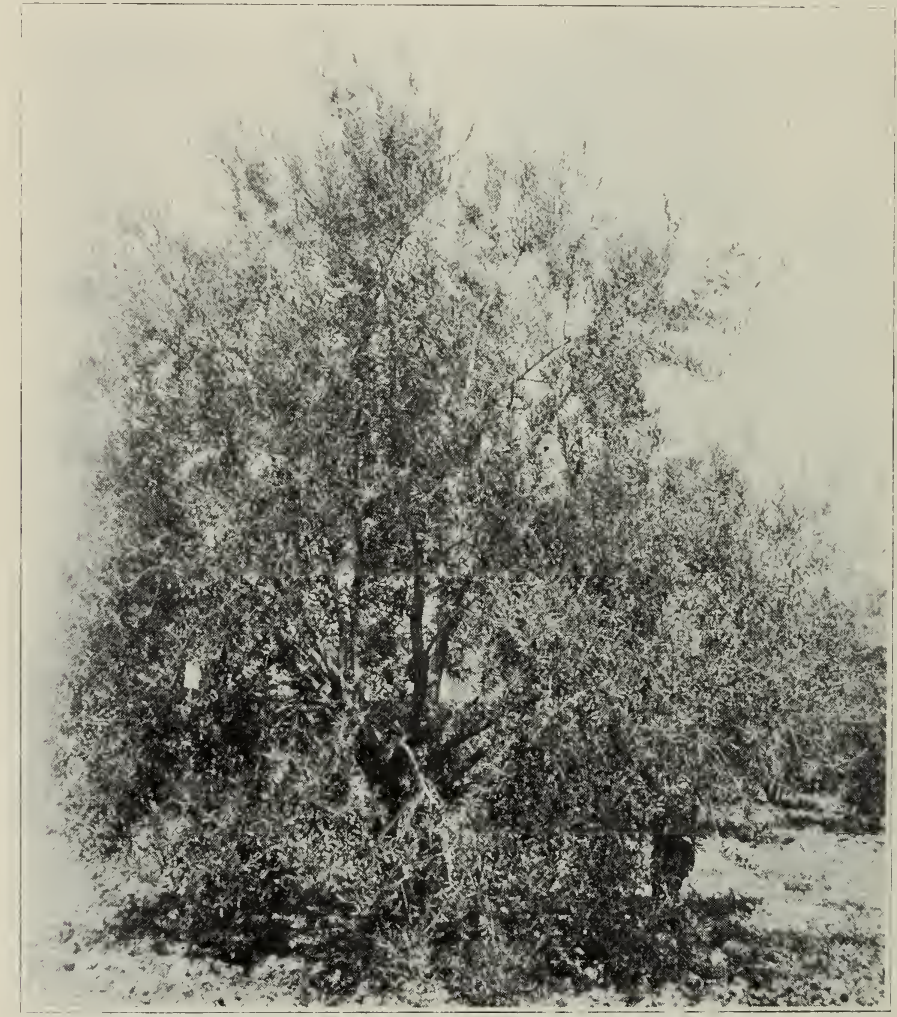

Fig. 5.-The same Ascolano tree as shown in figure 4, after pruning. Illustrates system $A$ after pruning in 1929 .

The skirt of small branches on the lower part of the tree was thinned out lightly at each annual pruning. The growth on the scaffold branches of the Manzanillo was thinned out annually in order to lighten the weight of crop and foliage and reduce the tendency to droop. This was done also with Sevillano and Ascolano in cases where they showed the same tendency. The thinning was done by removing laterals or portions of laterals. No thinning was done on the scaffold branches of the Mission until the fifth winter.

At the fifth winter pruning, most of the surplus branches which had 
heen held back by annual pruning were removed entirely and the growth on the scaffold branches, where very dense, was thinned out to prevent overbearing the following season. This thinning out of laterals on the scaffold branches was fairly heavy with the Manzanillo, Sevillano, and Ascolano, and very light with the Mission (figs. 3 and 6).

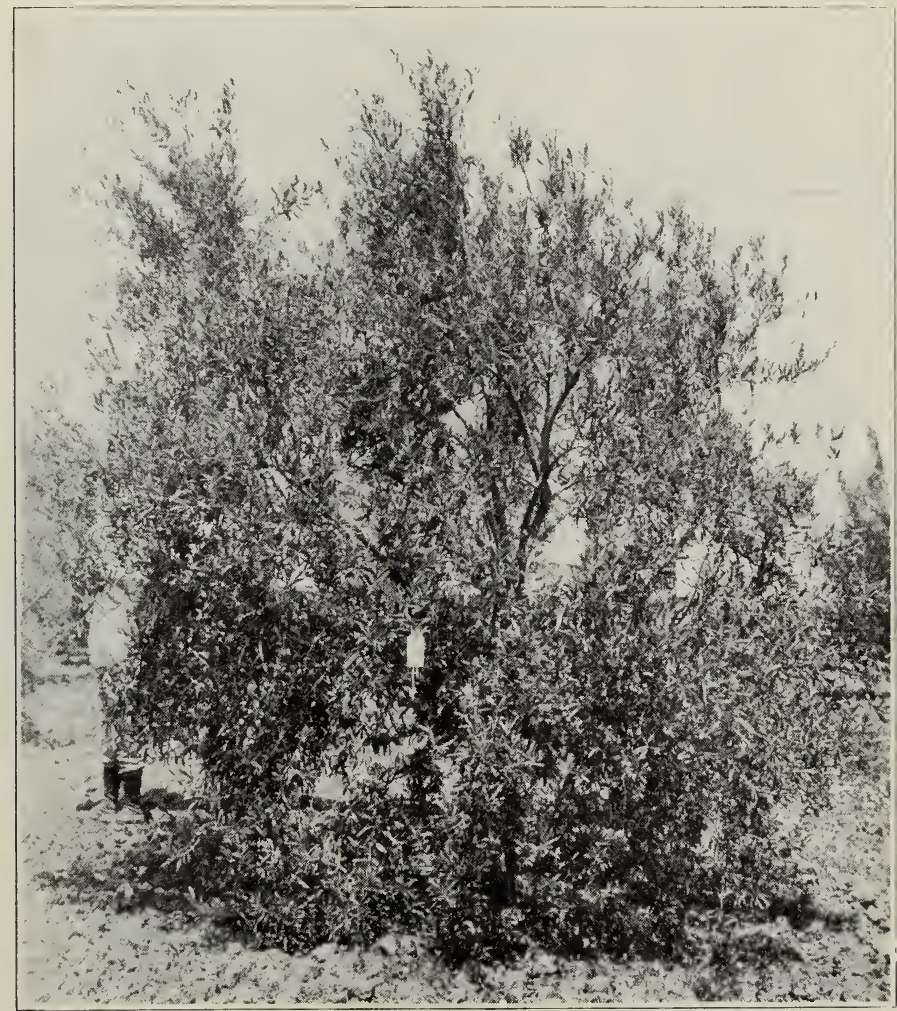

Fig. 6.-Ascolano tree 5 years old which has been shaped by light annual pruning. Illustrates system $C$ after pruning in 1929 .

System D: The pruning under this system was identical with that of system $C$, but in addition to pruning, mechanical means were employed where needed to hold the scaffold branches in position for one or two seasons. On the Mission a double-pointed piece of hardwood was inserted between crowding scaffold branches to hold them apart for one season, after which they maintained their relative positions without the spreader. Not more than three spreaders were used on any tree and most of the trees did not require any.

With the Manzanillo trees under this system the scaffold branches 
were supported during the second and third seasons by bands of burlap about 3 inches wide passed around the tree and nailed to a stake about $41 / 2$ feet high (figs. 7 and 13 ). Where individual scaffold branches showed a strong tendency to droop and could not be supported by this means, owing to the limited height of the stake, they were supported by

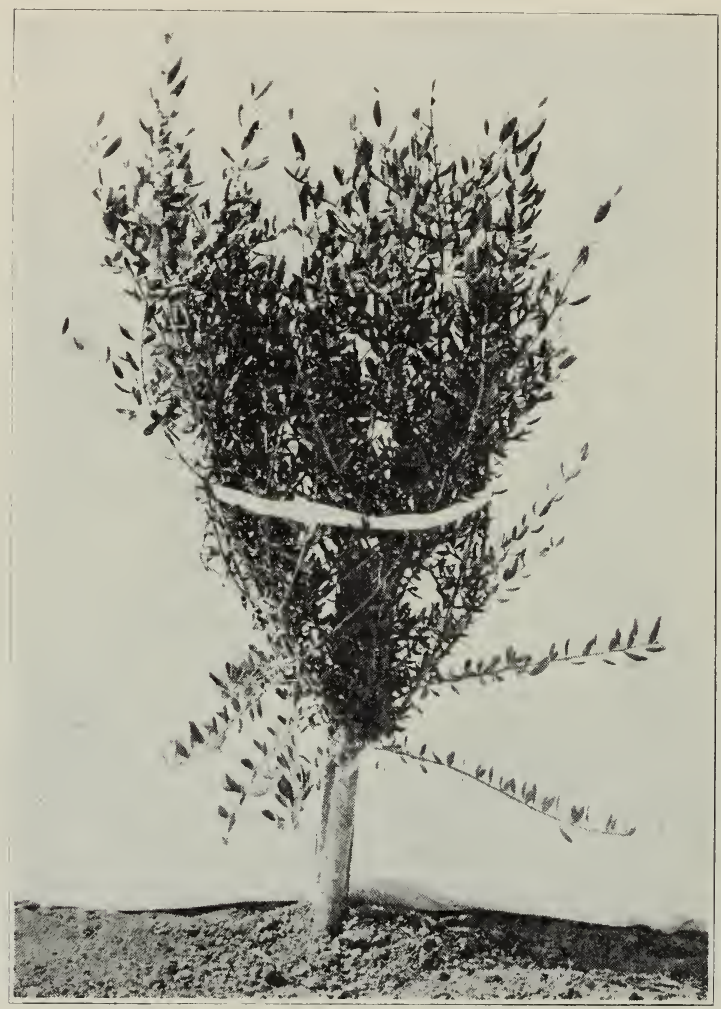

Fig. 7.-Manzanillo tree 2 years old supported by a band of eloth passed around the tree and the ends nailed to a stake.

tying to one or two opposing branches by means of tarred grape twine. The twine was fastened to screw-eyes inserted in the respective branches. Many branches were supported in this manner during the third season and a few during the fourth season. No tying was done after the fourth season.

The scaffold branches of the Sevillano and $\Lambda$ scolano grew very nearly in the desired position and required practically no artificial support. $\mathrm{An}$ occasional branch was kept in place with tarred grape twine and screweyes as was done with the Manzanillo. 
System E: The trees under this system were heavily pruned annually. At the first winter pruning three or four branches were selected for scaffold branches and all others removed. These selected branches were cut back to about 6 inches and all of their lateral branches removed. At the second and subsequent prunings, all new branches and twigs starting

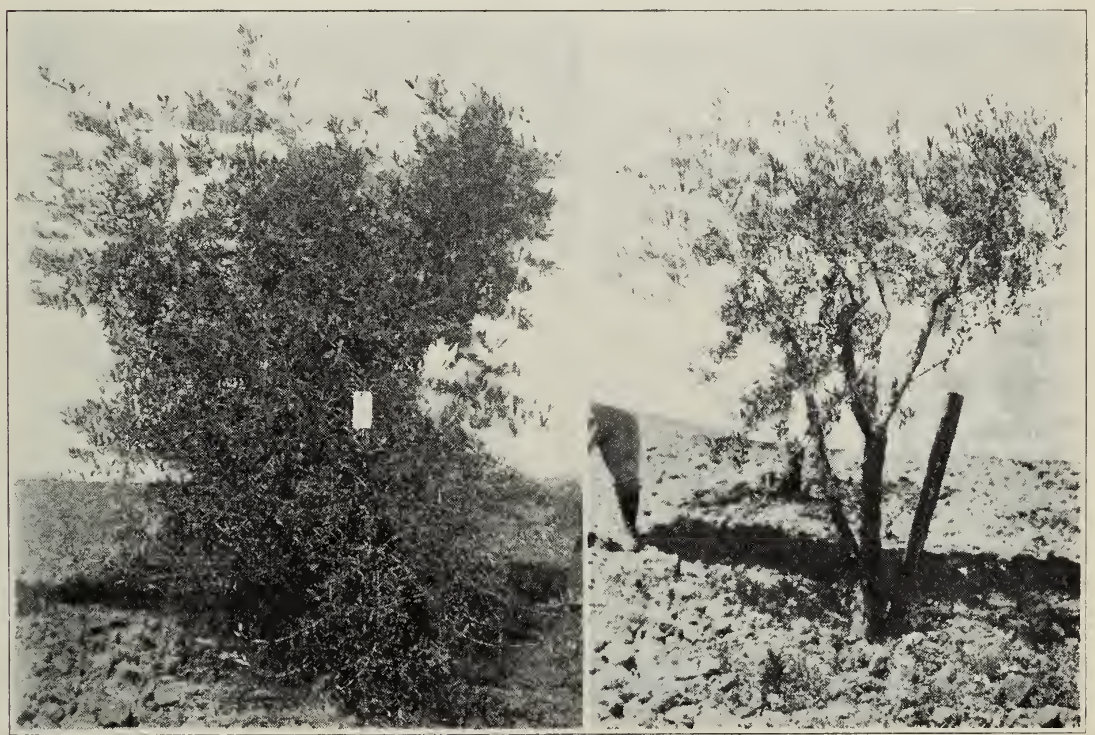

Fig. 8.-Ascolano tree 5 years old which has been severely pruned annually. Left, before pruning in 1929. Right, the same tree after pruning in 1929 .

from the trunk were removed and the growth on the seaffold branches was heavily thinned. Any scaffold branch not growing in the desired direction was cut back to a lateral extending in the proper direction and the other branches were cut back to a similar height. This type of pruning was continued for five successive seasons. It was intended to be as nearly as possible a duplication of the heavy annual pruning practiced in the previous experiment and reported in Bulletin 348, but on a different variety-Ascolano (fig. 8). Mission was used in the former investigation. 


\section{SPACING AND ARRANGEMENT OF THE TREES}

An orchard of 168 trees was planted in March, 1924, at the University Farm, Davis, in accordance with the planting plan shown in figure 9 .

A permanent orchard of trees spaced $30 \times 30$ feet was desired for future experiments in pruning bearing trees. In order, however, to pro-

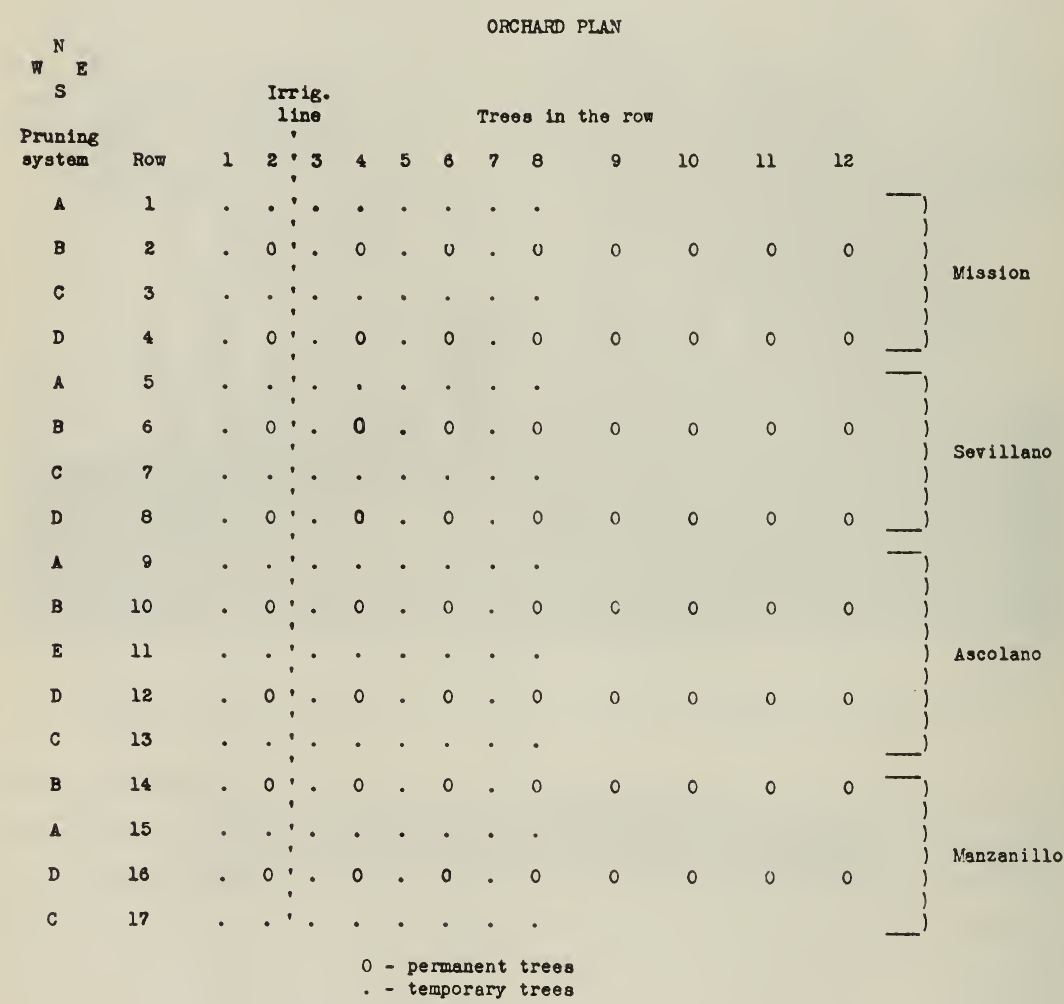

Fig. 9.-Planting plan of the pruning plot.

vide a larger number of young trees upon which to try the various systems of pruning young trees, half of the area of the plot was planted $15 \times 15$ feet and the other half $30 \times 30$ feet; three-fourths of the closeplanted trees were to be removed when they reached bearing age. This spacing was sufficient to allow uniform development of the individual trees up to bearing age, and all the trees of the orchard were therefore used in the tests. The plot was bordered on all four sides by avenues or roadways 20 feet or more in width. 


\section{PLANTING}

The Mission trees were grown from cuttings in a nursery at Davis. At the time of planting in the orchard they were several years old and the circumference of the trunks (measured 4 inches above the ground level) varied from 8.4 inches for the largest to 5.5 inches for the smallest (see table 1).

The Manzanillo, Sevillano, and Ascolano trees were purchased from commercial nurseries. All were grafted on Redding ${ }^{4}$ stock and their exact age was unknown. At 4 inches above the ground level the Manzanillo trees varied in trunk circumference from 1.9 to 1.1 inches; the Sevillano from 1.7 to 1.1 inches; and the Ascolano from 2.1 to 1.1 inches.

Pruning before planting consisted, in the case of the Mission, in removing all except two or three of the largest branches-removing all laterals and foliage from the retained branches, and shortening them to about 4 inches. The trunk was cut back to not over 30 inches from the ground level. All branches and leaves were removed from the trunks of the Manzanillo, Sevillano, and Ascolano trees, and the trunks were cut back to within 24 inches of the ground level.

The trees were graded before planting according to circumference of trunk, the measurements being taken at the ground level of the nursery row.

In planting, the trees were arranged according to size in order to avoid competition between small and large trees. For example in the case of the Mission, beginning with the largest tree and progressively using trees of smaller size, the order of planting was as follows : Row 1, tree 1 ; row 2 , tree 1 ; row 3 , tree 1 ; row 4 , tree 1 ; row 4 , tree 2 ; row 3 , tree 2 ; row 2 , tree 2 ; row 1 , tree 2 ; row 1 , tree 3 , etc. After planting, the trees were whitewashed and were given a light irrigation.

For permanent record, circumference measurements were made after planting, at a height of approximately 4 inches above the soil level (table 1).

\section{CULTURAL CONDITIONS}

The soil of the plot belongs to the Yolo loam series and, to a depth of 4 feet, is without marked variations in texture over the area of the plot. Before planting, the land had been subsoiled 18 inches deep at intervals of 3 feet and fallowed for one season. It had been in annual crops for some years and was well leveled for irrigation.

${ }_{4}^{4}$ A strong-growing variety often misnamed Picholine. 


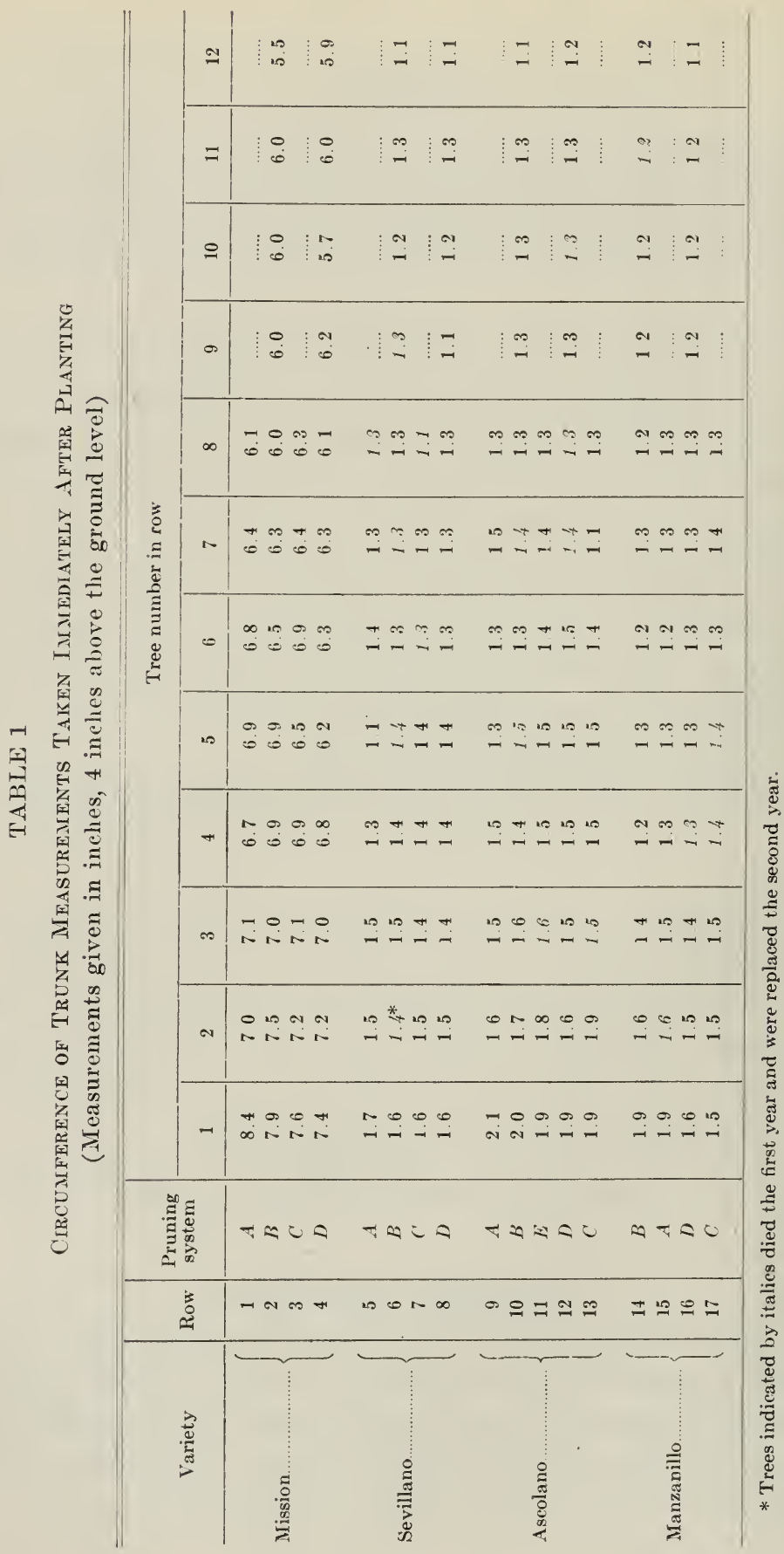


'The planting, subsequent cultivation, and irrigation were carried out uniformly with all plots. No defect in cultural care was noted except that in October, 1931, the fruit of several of the close-planted trees shriveled owing to insufficient soil moisture.

At the end of the first growing season several trees were dead and a few more had grown poorly. All dead and weak trees were replaced in the spring of 1925 with good trees of similar size and of the same variety. The number of replaced trees was : Mission, 0; Sevillano, 7; Ascolano, 7; Manzanillo, 5 . Their position in the plot is shown by italies in table 1 .

\section{DATA COLLECTED}

Annual measurements and records were made for each tree, showing:

1. Circumference of the trunk, measured by means of a steel tape passed around the trunk at a height of approximately 4 inches from the ground level. The trunk circumferences were then converted to trunk cross-section areas (table 4 and fig. 10).

2. Weights of prunings (table 2 ).

3. Estimated fraction (percentage) of the total foliage removed by pruning during each of the first three years (table 3 ).

4. Height of the tree-the average height of an imaginary line drawn across the two highest points of the tree (table 5 ).

5. Spread of the tree-the greatest distance in an east and west direction, between imaginary lines forming opposite sides of the general contour of the individual tree (table 5 ).

6. Weights of crops (table 6).

7. Character of the crop as to graded sizes (table 6 ).

\section{DISCUSSION OF THE DATA}

The measurements of tree and crop indicate the specific influence of pruning and the relative merits of the several systems of training when applied to the four varieties. The results are summarized in tables 1 to 6 .

Weights of Prunings.-The individual weights of the prunings of each tree have been averaged for each row and year (table 2). The figures include the prunings from all trees-original plantings and replants. Since the pruning was done in February or March of each year the first winter pruning was in 1925, the second in 1926, and so on. The trees developed slowly and unevenly during the first two years. The pruning during these years was in accordance with the plan except that any trees of the $C$ and $D$ systems which had made an insufficient growth 
for the selection of scaffold branches were left unpruned until the second winter (1926).

There are no consistent differences in the total weight of prunings taken with the systems $A, B, C$, and $D$ during the first 6 years. With system $E$ the total weight of prunings exceeded the average for the variety (Ascolano) in the other systems by 53 per cent (table 2 ).

\section{TABLE 2}

Average Weight Per Tree of Prunings Removed Each Year, in Pounds

\begin{tabular}{|c|c|c|c|c|c|c|c|c|c|}
\hline Variety & Row & $\begin{array}{l}\text { Pruning } \\
\text { system }\end{array}$ & $1925 *$ & 1926 & 1927 & 1928 & 1929 & 1930 & $\begin{array}{l}\text { Total of } \\
\text { six years }\end{array}$ \\
\hline \multirow{4}{*}{ Mission } & 1 & $A$ & ......... & .......... & ......... & $\ldots \ldots \ldots$ & 87.1 & 9.0 & 96.1 \\
\hline & 2 & $B$ & $\ldots \ldots \ldots$ & ......... & 29.0 & $\ldots \ldots \ldots$ & 47.7 & 13.6 & 90.2 \\
\hline & 3 & $C$ & 0.26 & 1.4 & 11.4 & 15.4 & 12.1 & 27.7 & 68.2 \\
\hline & 4 & $D$ & 024 & 1.9 & 15.0 & 16.5 & 17.8 & 30.4 & 81.8 \\
\hline \multirow{4}{*}{ Sevillano. } & 5 & A & & $\ldots \ldots$. & .. . & ......... & 37.2 & 14.3 & 51.5 \\
\hline & 6 & $B$ & $\ldots$ & $\ldots \ldots \ldots$ & 7.5 & $\ldots \ldots$ & 21.8 & 123 & 40.7 \\
\hline & 7 & $C$ & 000 & 12 & 31 & 101 & 16.3 & 24.2 & 54.8 \\
\hline & 8 & $D$ & 0.02 & 1.8 & 2.9 & 11.2 & 13.6 & 20.5 & 49.9 \\
\hline \multirow{5}{*}{ Ascolano. } & 9 & $A$ & $\ldots \ldots \ldots$ & ......... & $\ldots$ & $\ldots \ldots$. & 43.8 & 16.9 & 60.7 \\
\hline & 10 & $B$ & $\ldots \ldots \ldots$ & $\ldots \ldots$. & 9.5 & $\ldots . .$. & 26.4 & 12.3 & 47.3 \\
\hline & 11 & $E$ & 004 & 39 & 92 & 171 & 29.7 & 16.5 & 76.6 \\
\hline & 12 & $D$ & 0.02 & 17 & 2.6 & 10.6 & 130 & 161 & 44.0 \\
\hline & 13 & $C$ & 0.02 & 08 & 15 & 10.6 & 156 & 19.4 & 47.7 \\
\hline \multirow{4}{*}{ Manzanillo.... } & 14 & B & ....... & ........ & 5.5 & ....... & 9.2 & 4.0 & 20.2 \\
\hline & 15 & $A$ & ........ & $\ldots \ldots$. & $\ldots \ldots$ & ......... & 19.6 & 37 & 23.3 \\
\hline & 16 & $D$ & 007 & 06 & 1. 1 & 6.6 & 11.2 & 17.4 & 37.0 \\
\hline & 17 & $C$ & 007 & 0.7 & 1.5 & 4.8 & 8.8 & 11.4 & 27.1 \\
\hline
\end{tabular}

* The pruning was done in February or March of the year indicated.

The percentage of the foliage removed from each tree by pruning was carefully estimated for the first three prunings. At the fourth and subsequent prunings the trees were so large that such estimates were very difficult to make and they were discontinued. Table 3 gives the average estimated percentage of foliage removed from the trees of each row for each of the first three seasons.

In April, 1931, all of the trees of rows 1 and 3, and trees 1, 3, 5, and 7 of rows 2 and 4 were removed and weighed in order to make direct comparison of the amount of growth made by the annually pruned trees of systems $C$ and $D$ with that made by the trees of systems $A$ and $B$ which had not been pruned each year. The trees were first cut off at a convenient height, and weighed. The stumps were then pulled and the roots cut off close to the base of the trunk. The trunks were weighed and their weights added to the respective top weights. No attempt was made to 
obtain the weight of the roots. To the weight of each tree was added the total weight of prunings removed from it during the previous years.

The mean weight of the total growth-weight of the tree plus all previous prunings-of the annually pruned trees (systems $C$ and $D$ ) was $454.9 \pm 36.8$ pounds; while that of the trees not annually pruned (systems $A$ and $B$ ) was $519.1 \pm 21.2$ pounds. The difference is not

TABLE 3

Average Estimated Percentage of the Foliage Removed by Pruning

\begin{tabular}{|c|c|c|c|c|c|}
\hline Variety & Row & $\begin{array}{l}\text { Pruning } \\
\text { system }\end{array}$ & 1925 & 1926 & 1927 \\
\hline Mission... & $\begin{array}{l}1 \\
2 \\
3 \\
4\end{array}$ & $\begin{array}{l}A \\
B \\
C \\
D\end{array}$ & $\begin{array}{l}7 \\
6\end{array}$ & $\begin{array}{c}\ldots \\
\ldots \\
5 \\
7\end{array}$ & $\begin{array}{l}\ldots . \\
34 \\
14 \\
19\end{array}$ \\
\hline Sevillano..... & $\begin{array}{l}5 \\
6 \\
7 \\
8\end{array}$ & $\begin{array}{l}A \\
B \\
C \\
D\end{array}$ & $\begin{array}{c}\ldots . \\
0 \\
8 \\
8\end{array}$ & $\begin{array}{l}\ldots . \\
\ldots . \\
24 \\
34\end{array}$ & $\begin{array}{l}\ldots . \\
22 \\
13 \\
12\end{array}$ \\
\hline$\Lambda$ scolano $\ldots . . .$. & $\begin{array}{r}9 \\
10 \\
11 \\
12 \\
13\end{array}$ & $\begin{array}{l}A \\
B \\
E \\
D \\
C\end{array}$ & $\begin{array}{r}\ldots \\
\ldots . \\
34 \\
3 \\
3\end{array}$ & $\begin{array}{l}\ldots \\
\ldots \\
70 \\
35 \\
19\end{array}$ & $\begin{array}{r}\ldots \\
28 \\
70 \\
16 \\
6\end{array}$ \\
\hline Manzanillo.......... & $\begin{array}{l}14 \\
15 \\
16 \\
17\end{array}$ & $\begin{array}{l}B \\
A \\
D \\
C\end{array}$ & $\begin{array}{l}\ldots . \\
\ldots . \\
20 \\
25\end{array}$ & $\begin{array}{l}\ldots . \\
\ldots . \\
20 \\
32\end{array}$ & $\begin{array}{l}35 \\
\ldots . \\
12 \\
15\end{array}$ \\
\hline
\end{tabular}

significant and it appears that the trees under the two general types of pruning made approximately equal total growth over the period of the experiment ( 7 years).

Cross-Section Areas of Trunks.-The individual trunk circumference measurements were converted to cross-section areas and have been averaged for each row and each year as shown in table 4 . They are summarized graphically in figure 10.

The unpruned trees (system $A$, rows 1, 5, 9, and 15) were difficult to measure because of branches very close to the ground. It is probable that the measurements recorded for these trees are slightly greater than the actual circumferences. The figures indicate that the unpruned trees in rows 1, 5, and 9 of the Mission, Sevillano, and Ascolano varieties, respectively, made appreciably greater growth prior to 1929 than was made by the trees of these varieties under any of the other pruning systems. 
After the severe thinning out of the branches of these trees in 1929, the differences decreased and almost disappeared by 1931 (fig. 10).

With the Manzanillo trees the case is reversed. The trees unpruned up to 1929, and those lightly pruned only once prior to 1929 (systems $A$ and $B$, rows 15 and 14 ), made less growth than the annually pruned

TABLE 4

Average Trunk Cross-Segtion Area of the Trees of Each Row by Years, in Square Inches*

\begin{tabular}{|c|c|c|c|c|c|c|c|c|c|c|}
\hline Variety & Row & $\begin{array}{l}\text { Pruning } \\
\text { system }\end{array}$ & $1924 \dagger$ & 1925 & 1926 & 1927 & 1928 & 1929 & 1930 & 1931 \\
\hline \multirow{4}{*}{ Mission. } & 1 & $A$ & 3.83 & 3.88 & 6.68 & 1425 & 27.90 & 37.98 & 53.17 & $\begin{array}{l}\text { Trees } \\
\text { removed }\end{array}$ \\
\hline & 2 & $B$ & 3.46 & 3.57 & 5.81 & 13.72 & 22.37 & 33.08 & 47.66 & $72.17+$ \\
\hline & 3 & $C$ & 3.75 & 3.77 & 4.87 & 11.55 & 21.10 & 27.59 & 40.58 & Trees \\
\hline & 4 & $D$ & 3.32 & 3.53 & 5.53 & 1383 & 24.26 & 33.68 & 50.50 & 78.74 \\
\hline \multirow{4}{*}{ Sevillano. } & 5 & $A$ & 0.16 & 0.28 & 2.08 & 1023 & 23.25 & 32.46 & 45.01 & 51.31 \\
\hline & 6 & $B$ & 0.14 & 0.25 & 1.81 & 7.44 & 18.12 & 22.41 & 38.47 & 49.89 \\
\hline & 7 & $C$ & 0.16 & 0.26 & 1.58 & 6.40 & 16.62 & 2345 & 36.52 & 48.65 \\
\hline & 8 & D) & 0.14 & 0.26 & 146 & 5.66 & 13.98 & 23.00 & 3404 & 46.73 \\
\hline \multirow{5}{*}{ Ascolano } & 9 & $A$ & 0.19 & 0.31 & 1.83 & 7.11 & 18.85 & 26.57 & 35.73 & 50.90 \\
\hline & 10 & $B$ & 0.17 & 0.31 & 1.55 & 5. 21 & 12.40 & 20.82 & 36.49 & 49.63 \\
\hline & 11 & $E$ & 0.19 & 0.28 & 0.88 & 4. 17 & 9.16 & 13.30 & 18.26 & 24.54 \\
\hline & 12 & $D$ & 0.17 & 0.28 & 1.49 & 5.01 & 12.06 & 17.64 & 30.95 & 42.83 \\
\hline & 13 & $C$ & 0.19 & 0.29 & 1.41 & 4.42 & 11.41 & 19.65 & 32.67 & 43.01 \\
\hline \multirow{4}{*}{ Manzanillo... } & 14 & B & 0.14 & 0.19 & 0.78 & 2.03 & 411 & 7.36 & 14.15 & 20.89 \\
\hline & 15 & A & 0.17 & 0.23 & 0.67 & 2.48 & 3.88 & 6.98 & 13.64 & 20.65 \\
\hline & 16 & $D$ & 0.14 & 0.25 & 0.74 & 2.71 & 6.43 & 10.82 & 19.55 & 28.95 \\
\hline & 17 & $C$ & 0.16 & 0.25 & 0.73 & 2.08 & 5.94 & 9.90 & 19.02 & 24.44 \\
\hline
\end{tabular}

* The measurements were made in April of each year.

$\dagger$ Replants are omitted in averages for the years 1924 to 1928 inclusive but are included in those of 1929,1930 , and 1931 .

$\ddagger$ Trees 1, 3, 5, and 7 were removed from rows 2 and 4 in April, 1931. The figures given for these rows in the 1931 column are the averages of the remaining trees.

trees (systems $C$ and $D$, rows 17 and 16 ). Representing the size by the cross-section area of the trunk and taking $D$ as 100 per cent in each year, the mean size of the trees of $A$ and $B$ for the years 1927 to 1931, inclusive, is respectively $83,63,67,71$, and 72 per cent. The cause of this difference is not evident.

The severely pruned Ascolano trees of row 11 made less growth than did the other trees of this variety. This difference in growth increased as the trees became older and in 1931 the average cross-section area of the trunks of the severely pruned trees was only 53 per cent of that of the average of the other Ascolano trees.

Height and Spread of the Trees.-Height and spread measurements 
were obtained for each year but only those taken at the end of the seventh year need be summarized. Table 5 shows the average height and spread of the trees of each row in 1931-the end of the seventh year-and also

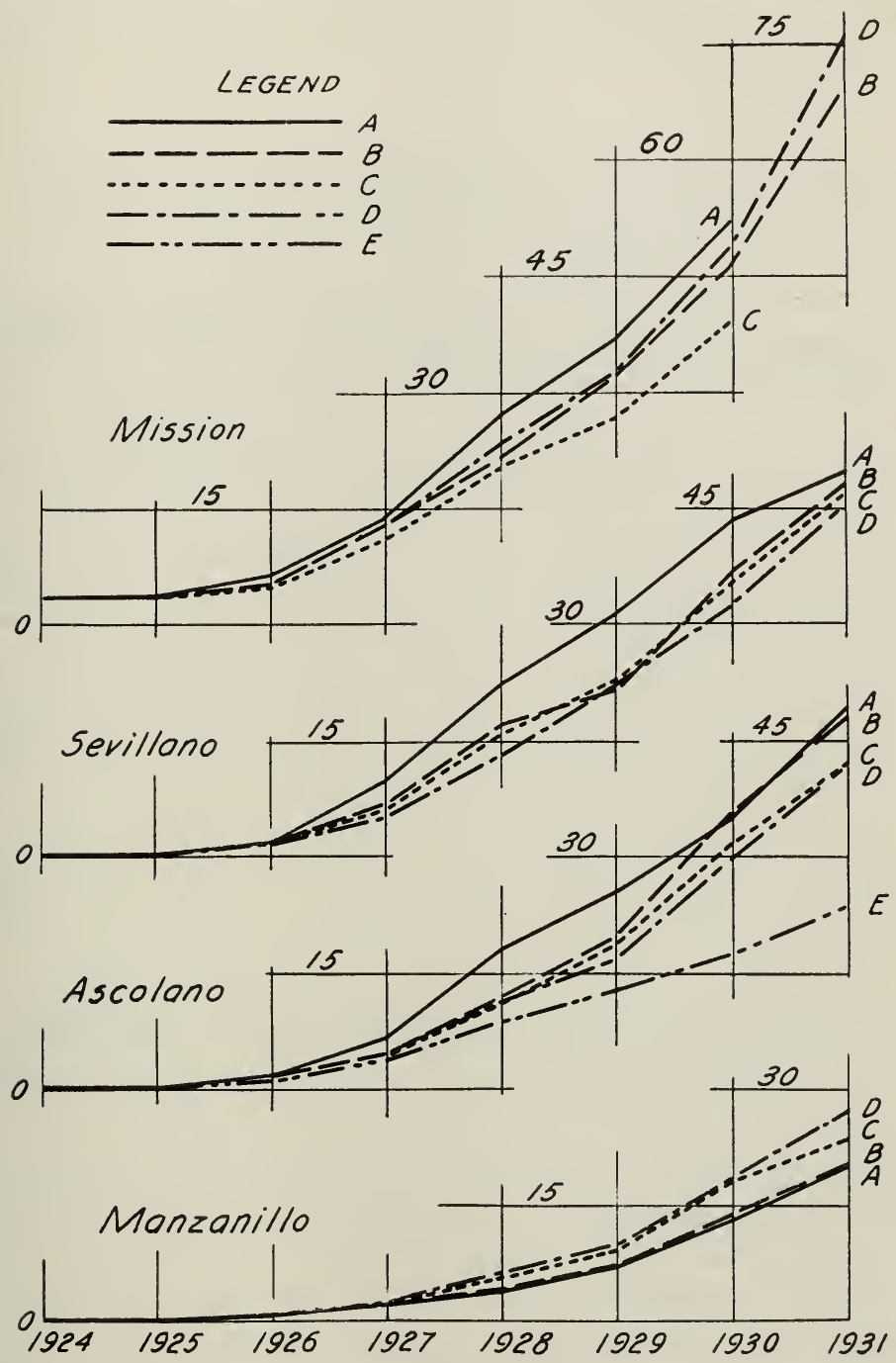

Fig. 10.-Growth of olive trees under systems $A, B, C, D$, and $E$ as shown by the cross-section areas of the trunks. The varieties are plotted separately but on the same scale showing average trunk cross-section areas in square inches for each year.

the product of the average spread multiplied by the average height. These figures do not show any appreciable differences in height or spread of Mission, Sevillano, or Ascolano trees pruned according to systems 
$A, B, C, o r^{\prime} D$. The severely pruned trees of row 11 (system $E$ ) are considerably smaller than those of the other four rows of Ascolano. It appears that the Manzanillo trees of rows 16 and 17 under pruning systems $D$ and $C$ are slightly taller than the trees of rows 14 and 15 which are under pruning systems $B$ and $A$, respectively, but they have the same spread.

\section{'TABLE 5}

Height and Spread of the Trees a't the End of Seven I tears (Averages of the trees of each row)

\begin{tabular}{|c|c|c|c|c|c|}
\hline Variety & Row & $\begin{array}{l}\text { Pruning } \\
\text { system }\end{array}$ & $\begin{array}{c}\text { Height, } \\
\text { feet }\end{array}$ & $\begin{array}{l}\text { Spread, } \\
\text { feet }\end{array}$ & $\begin{array}{l}\text { Height } \times \text { spread, } \\
\text { square feet }\end{array}$ \\
\hline \multirow{4}{*}{ Mission } & 1 & $A$ & & Trees removed & \\
\hline & 2 & $B$ & 18.7 & 14.8 & 275.5 \\
\hline & 3 & C & & Trees removed & \\
\hline & 4 & $D$ & 19.0 & 15.7 & 299.1 \\
\hline \multirow{4}{*}{ Sevillano. } & 5 & A & 144 & 14.1 & 203.4 \\
\hline & 6 & $B$ & 141 & 141 & 199.1 \\
\hline & 7 & C & 144 & 13.4 & 193.7 \\
\hline & 8 & D & 141 & 13.8 & 194.7 \\
\hline \multirow{5}{*}{ Ascolano. } & 9 & $A$ & 15.1 & 14.4 & 217.4 \\
\hline & 10 & $B$ & 15.4 & 148 & 227.0 \\
\hline & 11 & $E$ & 8.5 & 8.2 & 69.9 \\
\hline & 12 & $D$ & 148 & 141 & 208.7 \\
\hline & 13 & C & 14.4 & 14.1 & 203.4 \\
\hline \multirow{4}{*}{ Manzanillo } & 14 & $B$ & 10.8 & 11.2 & 120.5 \\
\hline & 15 & $A$ & 9.8 & 11.8 & 116.2 \\
\hline & 16 & $D$ & 12.5 & 11.8 & 147.4 \\
\hline & 17 & C & 11.8 & 11.8 & 139.9 \\
\hline
\end{tabular}

Crop.-There was no crop in 1927-the fourth season after planting-except a few scattered fruits on unpruned trees. In 1928 the unpruned trees (system $A$ ) bore a small crop; the lightly pruned trees (systems $B, C$, and $D$ ) a very light crop; and the severely pruned trees (system $E$ ) none. Spring frost reduced the 1929 crop. In 1930 the first crop of commercial importance was produced. The Sevillano, Ascolano, and Manzanillo varieties were harvested and graded. The Missions were frozen before they matured and were not harvested. Table 6 gives the average weight of crop for the trees of each row for 1928 to 1930, and the percentage of large-sized fruits in the 1928 and 1930 crops.

In 1928 the unpruned trees outyielded all others. This crop, however, was too small for the differences to be of much practical value. The 1929 and subsequent crops were not greatly different on the trees of any single variety under pruning systems $A, B, C$, and $D$. The severely 
pruned Ascolano trees of row 11 did not produce a crop of (ommereial importance within the 7-year period of the experiment.

Influence of the Variety.-Figure 10 shows the growth of the trees during the 7 years (except for two rows of Missions which were removed).

TABIE 6

SUMMARY OF CROP RECORDS

(Averages of the trees of each row for each year expressed in pounds)

\begin{tabular}{|c|c|c|c|c|c|c|c|c|}
\hline \multirow[b]{2}{*}{ Variety } & \multirow[b]{2}{*}{ Row } & \multirow{2}{*}{$\begin{array}{l}\text { Pruning } \\
\text { system }\end{array}$} & \multicolumn{2}{|c|}{1928} & \multirow{2}{*}{$\begin{array}{c}1929 \\
\begin{array}{c}\text { A verage } \\
\text { weight } \\
\text { per tree }\end{array}\end{array}$} & \multicolumn{2}{|c|}{1930} & \multirow{2}{*}{$\begin{array}{c}\text { Total } \\
\text { of } 3 \text { crops, } \\
\text { average } \\
\text { weight } \\
\text { per tree }\end{array}$} \\
\hline & & & $\begin{array}{c}\text { A verage } \\
\text { weight } \\
\text { per tree }\end{array}$ & $\begin{array}{l}\text { Per cent* } \\
\text { large size }\end{array}$ & & $\begin{array}{l}\text { Average } \\
\text { weight } \\
\text { per tree }\end{array}$ & $\begin{array}{l}\text { Per cent } \\
\text { large size }\end{array}$ & \\
\hline \multirow{4}{*}{ Mission } & 1 & A & 29.9 & 67 & 33.2 & ......... & $\ldots$. & .......... \\
\hline & 2 & $B$ & 14.7 & 53 & 29.0 & ......... & $\ldots$. & .......... \\
\hline & 3 & $C$ & 16.9 & 53 & 39.2 & .......... & $\ldots$ & ........ \\
\hline & 4 & $D$ & 17.8 & 51 & 46.4 & $\ldots \ldots \ldots$ & $\ldots$ & $\ldots \ldots$ \\
\hline \multirow{4}{*}{ Sevillano } & 5 & $A$ & 15.8 & 76 & 19.4 & 61.2 & 72 & 96.4 \\
\hline & 6 & $B$ & 46 & 88 & 11.0 & 574 & 81 & 73.0 \\
\hline & 7 & $C$ & 3.3 & 80 & 8.8 & 53.0 & 72 & 65.1 \\
\hline & 8 & D) & 3.5 & 91 & 14.7 & 55.0 & 73 & 73.3 \\
\hline \multirow{5}{*}{ Ascolano } & 9 & $A$ & 24.0 & 65 & 31.0 & 74.1 & 73 & 129.1 \\
\hline & 10 & $B$ & 11.9 & 62 & 22.7 & 72.2 & 74 & 106.7 \\
\hline & 11 & $E$ & 0.0 & $\ldots$ & 0.0 & 8.6 & 77 & 8.6 \\
\hline & 12 & $D$ & 3.7 & 71 & 18.0 & 72.2 & 75 & 93.9 \\
\hline & 13 & $C$ & 7.5 & 60 & 11.7 & 75.9 & 73 & 97.2 \\
\hline \multirow{4}{*}{ Manzanillo. } & 14 & $B$ & 44 & 88 & 06 & 19.4 & 91 & 24.4 \\
\hline & 15 & $A$ & 5.9 & 86 & 2.6 & 22.9 & 86 & 31.5 \\
\hline & 16 & $D$ & 2.9 & 90 & 1.8 & 33.0 & 93 & 37.6 \\
\hline & 17 & $C$ & 2.6 & 94 & 2.0 & 21.1 & 95 & 25.7 \\
\hline
\end{tabular}

* Per cent large size indicates the percentage, by weight, of the fruit which in short diameter exceeded the measurements as follows: for Mission 10/16 inch; for Sevillano 25/32 inch; for Ascolano 25/32 inch; for Manzanillo 11/16 inch.

† The 1929 crop was not graded.

$\ddagger$ The 1930 crop of Mission was frozen before maturity and was not harvested.

By 1930 the mean growth of the Manzanillo under all systems was only about one-half that of the Sevillano and Ascolano, while the growth of the Mission was about a third greater than these. The Manzanillo is naturally a slow grower but the more rapid growth of the Mission is due only in part to any inherent quality it may have in this respect. The Mission trees were older and larger when planted than were the other varieties after two years growth in the field. The greater development of the Mission trees is therefore apparently due to the larger size of the trees when planted. They were of about the same size in 1929 as the Sevillanos and Ascolanos were in 1930; and in 1930 the Missions were as large as the Sevillanos and Ascolanos were in 1931. 
Influence of the system of Pruning.-The retardation of growth caused by heary pruning is clearly shown by the trees under system $E$ when these are compared with the other Ascolano trees under systems $A, B, C$, and $D$. When planted, the trees were of similar size (see table 1 ). In 1927 the cross-section area of the trunks of the severely pruned trees

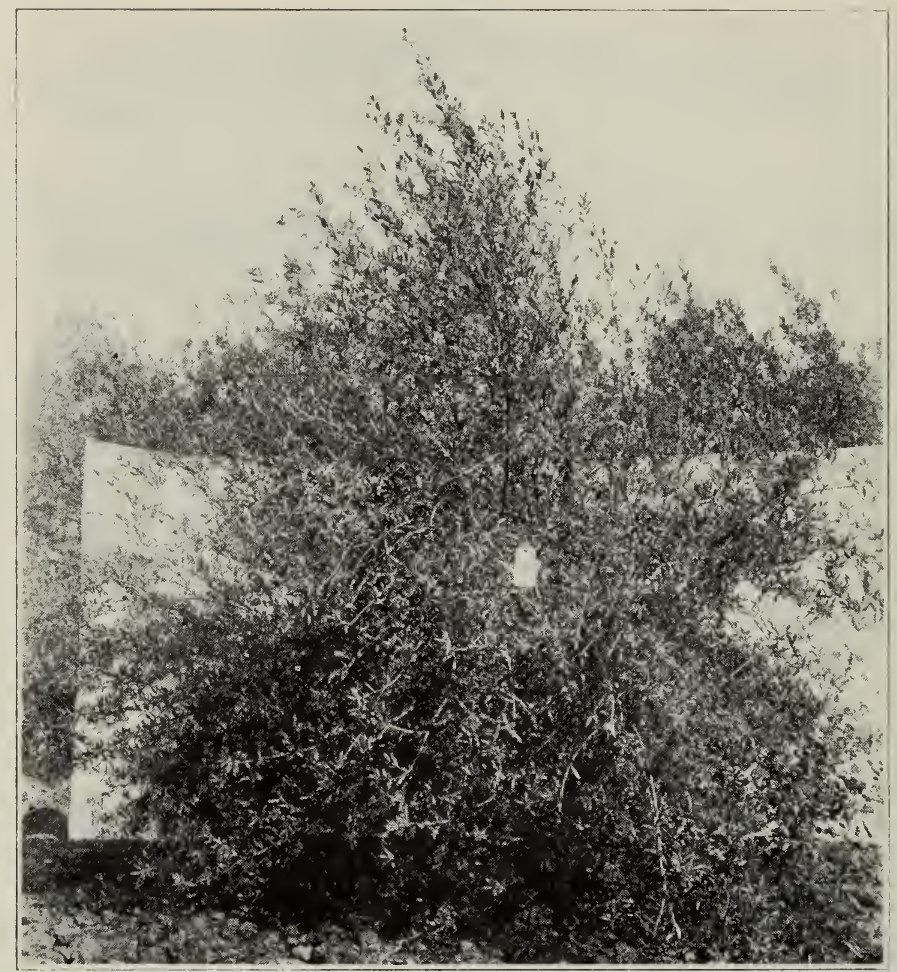

Fig. 11.-Manzanillo tree 5 years old having had no pruning. Illustrates system $A$ before pruning in 1929 .

was only 77 per cent of the average of the unpruned and lightly. pruned trees of the same variety, and fell to 67 per cent, 63 per cent, 54 per cent, and 53 per cent during the succeeding years. They bore no crop until 1930 and then only 8.6 pounds per tree which was 11.7 per cent of the mean crop of the other Ascolano trees of that year. The Mission, Sevillano, and Ascolano trees under system $A$ grew more rapidly than those under systems $B, C$, and $D$ prior to the opening up and thinning-out process begun in 1929 and completed in 1930. Following this heavy pruning the rate of growth of the trees under system $A$ decreased relatively to that of the trees under systems $B, C$, and $D$, and in 1931 there were no considerable differences in size. The rate of growth of the Mis- 
sion, Sevillano, and Ascolano trees under systems $B, C$, and $D$ was not greatly different at any time during the investigation (fig. 10 and table 4).

The Manzanillo trees under system $D$ grew faster after 1927 than did the trees of this variety under any other system. It is not clear why

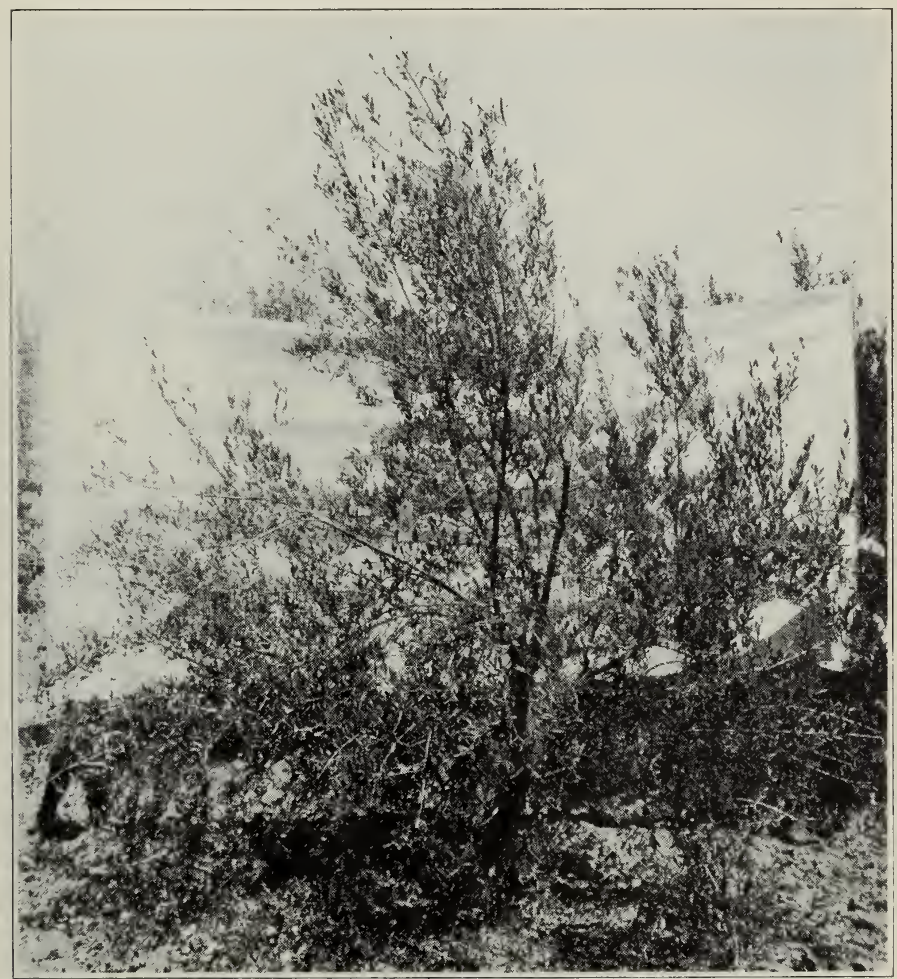

Fig. 12.-The same Manzanillo tree as shown in figure 11, after pruning in 1929. Illustrates system $A$ after pruning.

these annually pruned trees showed a greater growth than those under system $A$ which were unpruned until $1929 .^{5}$ The crop on all of the Manzanillo trees prior to 1930 was very light and in that year the trees under system $D$ outyielded those under any other system.

All of the trees of the Mission, Sevillano, and Ascolano varieties were well shaped at the end of the pruning experiment. The distribution of the scaffold branches on the trunk was best on the annually pruned trees

5 A possible explanation of the better growth of the annually pruned trees might be in their changed habit of growth. The unpruned trees were bush-like in character and the branches were long and drooping. The annually pruned trees were more upright in growth. It is well known that bending the branches of woody plants tends to check their growth. 
(systems $C$ and $D$ ). The main branches of the Mission trees which were opened up by heavy pruning in 1929 (systems $A$ and $B$ ) were slightly more spreading than those of the annually pruned trees (systems $C$ and D). (Compare figures 2 and 3.) The Sevillano and Ascolano trees showed little or no advantage in shape of tree of one pruning system over any

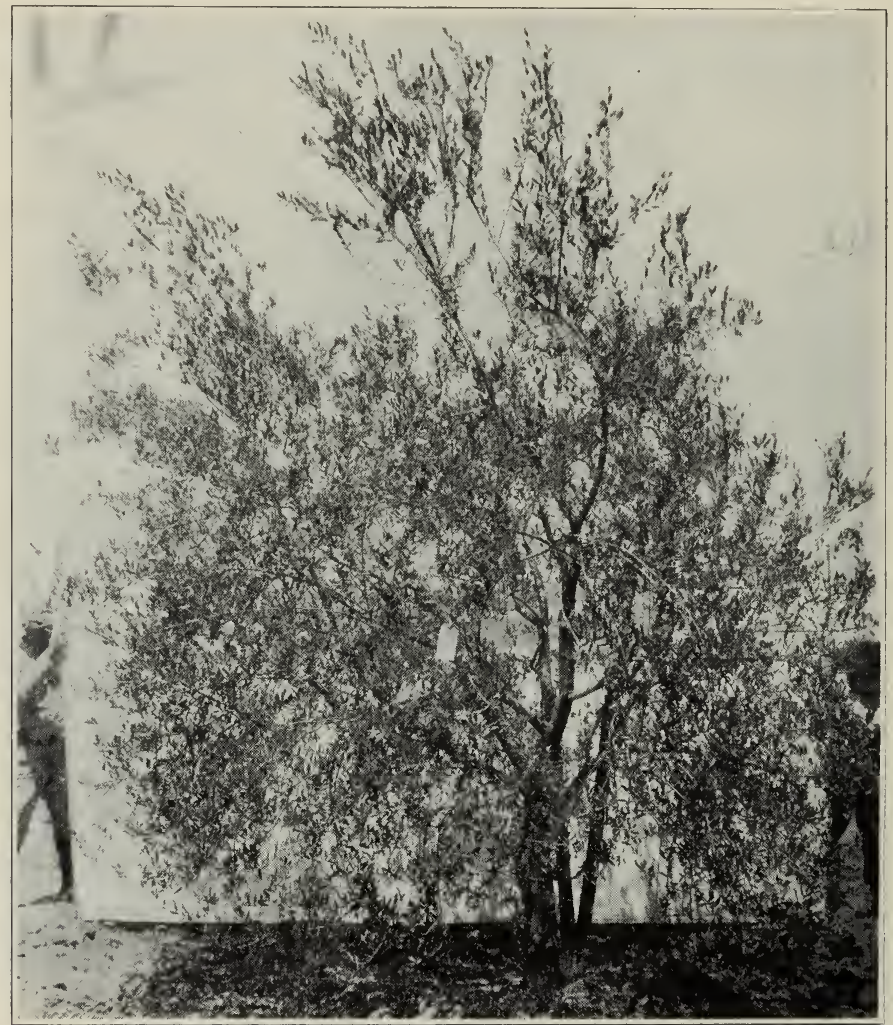

Fig. 13.-Manzanillo tree 5 years old shaped by tying and light annual pruning. Thinning the laterals on the main branches has lessened their tendency to droop. Illustrates system $D$ after pruning in 1929.

of the others. Figure 4 shows a five-year-old Ascolano tree of system $A$ before pruning and figure 5 shows this same tree after pruning in 1929 . One of the five-year-old Ascolano trees lightly pruned annually is shown in figure 6. The annually pruned Manzanillo trees (systems $C$ and $D$ ) were slightly taller and more upright than those pruned only once (system $A$ ) or twice (system $B$ ) which tended to be bush-like in shape during the first five years in the orchard (fig. 11; this same tree after pruning is shown in figure 12.) This difference was pronounced in 1929 
but less striking in 1931. The Manzanillo trees of system $D$ which had been supported by tying and internal bracing appeared to be better shaped in 1929 than those of system $C$ which had not been tied. Figure 13 shows a Manzanillo tree formed by annual pruning and tying. However, this difference was not apparent in 1931 or later and it appears doubtful that any permanent advantage resulted from the tying or bracing. The trees of the other three varieties showed little or no difference in this respect between systems $C$ and $D$.

The shaping of the trees mainly by a single heavy pruning (systems $A$ and $B$ ) resulted in many large pruning wounds on the trunks and scaffold branches of the trees. However, the wounds healed rapidly. The trees lightly pruned annually (systems $C$ and $D$ ) were nearly free from large wounds. Careful examination in April, 1933, failed to disclose any evidence of decay in any of the trees under systems $A, B, C$, and $D$.

The trunks of the severely pruned trees (system $E$ ) sunburned on the southwest side. Wood-rot fungi obtained entrance through the sunburned areas and when examined in April, 1933, every trunk of the severely pruned trees was badly decayed. The heartwood of several of the trunks was almost completely destroyed.

\section{SUMMARY AND CONCLUSIONS}

The slower development of the severely pruned Ascolano trees (system $E$ ) as compared with that of Ascolano trees less severely pruned clearly demonstrates the depressing effect of heavy pruning on young olive trees of this variety. The limitation of leaf surface not only diminished photosynthesis but exposed the trunk to the hot rays of the sun with consequent sunburn and fungus decay.

The depressing effect of the single severe pruning necessary to shape and thin the trees that were unpruned until 5 years old (system $A$ ) was approximately the same as the depressing effect of five light annual prunings (system $C$ ). The total weight of the removals in each of the two cases was also roughly the same for the Mission, Sevillano, and Ascolano varieties. The Manzanillo trees lightly pruned annually, on the contrary, appear to have developed faster than those left unpruned for three or for five years and this despite the fact that the total weight of removals was greater.

The form of the trees at the end of 7 years was not greatly different whether shaped by light annual pruning or by heavy pruning during the fifth year (or fifth and sixth years). Perhaps the Mission trees shaped mainly by a single pruning the fifth year were slightly superior in form 
to those shaped by annual pruning. On the other hand annual pruning produced slightly better-shaped Manzanillo trees ( 7 years old) than were obtained by one or two prunings. No considerable advantageous differences in form attributable to the pruning could be observed among the Ascolano and Sevillano trees.

Many large pruning wounds resulted from shaping the trees mainly by a single pruning (systems $A$ and $B$ ). The wounds healed rapidly, however, and no decay was observed. The trees lightly pruned annually were nearly free from large wounds. Wood-rot fungi entering through sunburned areas caused much decay in the trunks of the severely pruned Ascolano trees.

The trees left unpruned until 5 years old bore heavier crops in the fifth season than did the pruned trees. The crops during the sixth and subsequent years were about the same on the trees of each variety under all systems except severe pruning. The severely pruned trees did not produce a crop of commercial importance during the seven years.

Artificial supports of the types used in the $D$ system produced little or no permanent improvement in the form of the Mission, Sevillano, or Ascolano trees. Tying up the branches of the Manzanillo trees by passing a band of burlap cloth around the tree and supplementing this with internal bracing of the main scaffold branches produced a marked improvement in the shape which was apparent for at least five or six years. At seven years of age, however, the difference between the trees which had been tied and those not tied was not great and it appears doubtful that any permanent improvement has accrued from the tying.

\section{ACKNOWLEDGMENTS}

The plan of the experiment was originated by Professor F. T. Bioletti who also rendered valuable assistance in the preparation of the manuscript.

The cultural work was mostly done by Mr. G. Barovetto who also assisted in the planting, pruning, and measuring of the trees. 